\title{
nature
}

\section{Delaying COP26 is not a reason to delay climate action}

\section{Coronavirus has pushed climate talks back by a year. But action on global warming must not be postponed.}

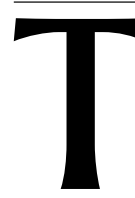

he first Conference of the Parties under the United Nations climate convention took place in Berlin a quarter of a century ago. By today's standards, it was a relatively modest affair, involving just a few thousand people, including government officials, scientists, environmentalists and journalists. By contrast, the event scheduled for this year in Glasgow, UK - the 26th Conference of the Parties (COP26) - would have attracted some 30,000 participants. But it has had to be postponed because of the coronavirus outbreak. Last week, we learnt that the delay will last for a year, with COP26 now due to take place in November 2021.

The decision to delay was unavoidable: a COP needs representatives of all countries to be present, which would not have been possible if those countries were at different stages of virus transmission and lockdowns. In Glasgow, the conference venue has been temporarily converted to a COVID-19 field hospital. An online meeting was considered, but rejected. Delegates rightly concluded that complex negotiations cannot be conducted using available virtual-meeting technologies.

But delay has risks, and principal among them is slower progress in the struggle against climate change. By the time COP26 was originally scheduled to begin, countries were expected to propose new commitments to bring emissions to net zero. And, at the conference, extra finance for lesswealthy countries was due to be proposed, making good on decades of promises that have not been kept.

The role of carbon markets was also to be discussed, along with nations' responsibility for damages caused by global warming. The meeting had a full agenda, and a delay of a year will have consequences - ultimately making it even harder to limit temperature increases to $1.5-2^{\circ} \mathrm{C}$ above pre-industrial levels, the main goal of the 2015 Paris climate agreement.

But countries do not need to wait until COP26 to take further action. Indeed, there are signs that some are planning to focus more public investments on green infrastructure and clean energy, rather than doubling down on a past marked by polluting fossil fuels. It is the least they can do.

Last week, the European Commission unveiled proposals for a $€ 750$-billion (US $\$ 833$-billion) post-coronavirus funding package that includes measures to accelerate the adoption of renewable energy technologies as part of a commitment to reduce emissions to net zero by 2050 . The package will, however, need to be agreed by the 27 member states and the European Parliament.

At the same time, China announced that, for the first time in decades, it will not set a target for economic growth. Not setting such a target will enable policymakers to prioritize innovative ideas for improving the environment and well-being, which can be difficult to do when a country's principal policy focus is economic growth.

When it comes to the actual climate talks, waiting another year does have one potential advantage. Many countries were unlikely to step up with ambitious climate plans this year, even before the COVID-19 crisis complicated matters. This is due, in part, to the uncertainty surrounding the United States' intentions following President Donald Trump's decision to pull out of the Paris agreement. The US position is likely to become more predictable after US voters have delivered their verdict in the presidential election in November.

If the Democrat candidateJoe Biden is elected, the United States is expected to rejoin the Paris accord and restore a more evidence-based approach to its climate-change decision-making. It will also revert to engaging more constructively with other countries. But if Trump is re-elected, that will signal to other countries - especially those in the European Union - that they should organize and press forwards with ambitious climate targets and funding pledges independently of the United States.

The latter scenario is likely to present the UK government with some challenges as it hosts COP26, along with next year's meeting of the Group of Seven large industrialized countries. As the United Kingdom exits the EU, it is loosening its ties to the EU's many collective decision-making structures. At the same time, the government is in active talks with the United States, seeking a closer relationship in areas including trade and research.

\section{Policy dilemma}

On climate policy, the United Kingdom could find itself trapped between a White House urging it to pay due attention to the US perspective, and most other countries, which will be advocating for action on the basis of the Paris consensus. British climate negotiators must do what is best for the planet, and act according to the best available evidence.

Five years ago, countries came together in Paris on a new agreement to curb greenhouse-gas emissions. They knew then that their pledges fell short of what was needed, and agreed to return to the table this year with new commitments. A further delay of a year gives countries more time to plan for more ambitious reductions. It also gives policymakers more time to think strategically as they work to bolster jobs, improve livelihoods and, ultimately, build more-resilient economic systems.

The pressure is on and countries must continue to act with urgency. They might think that they have carved out an extra year to prepare for $\mathrm{COP} 26$, but, in practice, there is no extra time. The climate clock is still ticking and by delaying emissions reductions, all countries have done is borrow against the planet's future. 